\title{
Justyna Karwowska
}

Uniwersytet Ekonomiczny we Wrocławiu

e-mail: justyna.karwowska@ue.wroc.pl

\section{ZNACZENIE ZMIAN NA RYNKU ROPY NAFTOWEJ DLA GOSPODARKI ARABII SAUDYJSKIEJ}

\section{THE IMPACT OF CHANGES ON THE CRUDE OIL MARKET FOR THE ECONOMY OF SAUDI ARABIA}

DOI: $10.15611 / \mathrm{e} 21.2017 .4 .12$

JEL Classification: Q43, Q41, N55, N75

Streszczenie: W drugiej połowie 2014 roku doszło do gwałtownych spadków cen ropy naftowej, co okazało się dużym zaskoczeniem zarówno dla konsumentów, jak i dla producentów tego surowca. Dla tych drugich zjawisko to było zdecydowanie negatywne, a efekt ten pogłębiły dodatkowo bardzo wysokie ceny, utrzymujące się przez kilka ostatnich lat. Wyjątkowo dobra koniunktura była bowiem powodem, dla którego eksporterzy ropy znacznie zwiększyli wydatki budżetowe, co miało miejsce m.in. w przypadku Arabii Saudyjskiej. W takich okolicznościach obniżki cen sprawiły, że konieczne stało się skorzystanie z rezerw walutowych. W perspektywie długoterminowej krok ten nie rozwiązuje jednak problemu deficytu, w związku z czym władze zdecydowały się wprowadzić reformy gospodarcze. Celem artykułu jest przedstawienie dotychczas opracowanych reform, których ramy określa program Vision 2030, będący 14-letnią strategią uniezależnienia się od jednego źródła przychodu. Oprócz tego w publikacji sporo miejsca poświęcono analizie przyczyn stojących za spadkiem cen czarnego złota, a także opisaniu funkcjonowania gospodarki Arabii Saudyjskiej, która w znacznej mierze jest oparta właśnie na zyskach ze sprzedaży surowca. Utrzymanie takiego modelu, przy obecnych cenach ropy, jest wysoce nierentowne i groziłoby bankructwem, w związku z czym reakcja władz Arabii Saudyjskiej musiała zostać oparta głównie na dywersyfikacji gospodarki.

Słowa kluczowe: ropa naftowa, surowce energetyczne, Arabia Saudyjska, petrostates, OPEC.

Summary: In the second half of 2014 there was a sharp decline in oil prices, which turned out to be a big surprise for both consumers and producers of petroleum. For the latter, this phenomenon was definitely negative, and this effect was further aggravated by the very high prices of crude oil in the last few years. The exceptionally good business conditions were the reason why oil exporters significantly increased budget expenditures, e.g. in case of Saudi Arabia. Under such circumstances, price reductions have made it necessary to use the foreign exchange reserves. In the long run, however, this step does not address the deficit problem, so the authorities have decided to introduce economic reforms. The aim of the article is to present the reforms that have been devised, outlined in the Vision 2030, a 14-year strategy aiming to become independent from the only source of income. Moreover, significant amount of space has been devoted to analyzing the causes behind the decline in prices of black gold, 
as well as describing the functioning of the Saudi economy, which is largely based on gains from the sale of crude oil. Maintaining such a model at current oil prices is highly unprofitable and threatens bankruptcy, so the reaction of the Saudi authorities had to be based mainly on the diversification of the economy..

Keywords: petroleum, energy commodities, Saudi Arabia, petrostates, OPEC.

\section{Wstęp}

W dzisiejszych czasach, mimo rosnącej pozycji alternatywnych źródeł energii, ropa naftowa nadal jest uznawana za podstawę dla całej światowej gospodarki. W drugiej połowie 2014 roku ceny surowca drastycznie spadły - ze średnio 108 dol. za baryłkę w czerwcu do 47 dol. zaledwie siedem miesięcy później. Zjawisko to miało duży wpływ na światową gospodarkę - importerzy surowców mogli korzystać z taniej energii, co napędzało ich wzrost gospodarczy, z drugiej strony jednak dla wielu krajów sytuacja ta była niezwykle uciążliwa. Państwa, które swój rozwój oparły na eksporcie ropy, w latach 2011-2014 odnotowały nadzwyczajne zyski, a co za tym idzie, zwiększyły wydatki. W takim stanie zaskoczyły je spadki cen surowca, co rzecz jasna odbiło się na możliwości sfinansowania całego budżetu. Warto zwrócić uwagę, iż do tej pory skutki tak nagłych fluktuacji miały negatywny wpływ na gospodarki państw rozwiniętych, szczególnie Stanów Zjednoczonych, i to właśnie $\mathrm{z}$ ich perspektywy były analizowane. Obecnie, gdy kraje takie jak Arabia Saudyjska odgrywają coraz większą rolę na arenie międzynarodowej, także ich problemy stają się szeroko komentowane, szczególnie ze względu na możliwość oddziaływania na światowe ceny ropy naftowej.

Celem publikacji jest przedstawienie genezy ostatnich zmian na rynku ropy, ich wpływu na funkcjonowanie gospodarki Arabii Saudyjskiej, a także wybranych działań tego państwa, mających na celu złagodzenie negatywnych skutków szoku. W tekście zarysowano przyczyny wystąpienia ostatniego załamania cen, sposoby przeciwdziałania tym wydarzeniom postulowane przez Organizację Krajów Eksportujących Ropę Naftową (Organization of the Petroleum Exporting Countries OPEC), a także opisano sposób funkcjonowania saudyjskiej gospodarki. Szczególne miejsce poświęcono programowi Vision 2030, którego jednym z głównych założeń jest uniezależnienie państwa od zysków ze sprzedaży ropy.

\section{Analiza rynku ropy naftowej w latach 2010-2016}

Dla gospodarek opartych na eksporcie ropy naftowej ceny tego surowca stanowią o „być albo nie być”. Mowa tu nie tylko o potencjale gospodarczym i możliwości utrzymania państwa, ale też o relacjach międzynarodowych - nie da się bowiem ukryć, że czarne złoto stanowiło istotny czynnik w budowaniu pozycji wielu krajów na arenie międzynarodowej. Dzięki swoim zasobom państwa OPEC były w stanie 
przez wiele lat dyktować warunki na rynku ropy naftowej. Warto zwrócić uwagę na fakt, że kraje członkowskie wiele zyskały na utrzymujących się na początku XXI wieku cenach ropy - na przykład omawiana Arabia Saudyjska utrwaliła swoją pozycję regionalnego hegemona. Ostatnimi czasy jednak wpływ organizacji zdaje się słabnąć, a państwa w niej zrzeszone muszą zmierzyć się z problemem, który wpisany jest w funkcjonowanie wszystkich gospodarek monogałęziowych, czyli drastycznym spadkiem cen towaru, na którym opiera się cały kraj. Ceny surowca osiągają dziś historycznie niski poziom, co w oczywisty sposób wpływa na dochody z eksportu w całym regionie Zatoki Perskiej, także w Arabii Saudyjskiej. W obecnej sytuacji dalszy rozwój eksporterów surowca stoi pod znakiem zapytania, gdyż długotrwałe uzależnienie od jednego dobra może prowadzić do nadmiernej wrażliwości gospodarki na jego niską cenę, a co za tym idzie - problemów budżetowych. Warto więc zastanowić się nad możliwymi konsekwencjami polityczno-ekonomicznymi niskich cen ropy w tzw. petrostates, czyli krajach, które swoje bogactwo zawdzięczają jej sprzedaży.

Po ekstremalnie wysokich cenach ropy naftowej w latach 2007-2014 przyszła pora na drastyczne spadki. W drugiej połowie 2014 roku ceny surowca spadły gwałtownie, kończąc okres czterech lat stabilności cenowej, gdy cena baryłki utrzymywała się w okolicach 105 dol. (od początku 2011 roku do czerwca 2014 roku cena odmiany Brent mieściła się w przedziale 95-125 dol.). Pod koniec 2014 roku cena ta spadła do 59 dol. i dalej się obniżała. Ropa naftowa w niecałe sześć miesięcy potaniała o prawie $50 \%$. W tym samym czasie produkty rolne potaniały zaledwie o $7 \%$, a metale i inne surowce mineralne (z wyjątkiem ropy) - tylko o $3 \%$.

Niemniej jednak zjawisko to nie było pierwszym przypadkiem znacznych spadków ceny ropy. Od 1984 do 2013 roku wystąpiło pięć epizodów odznaczających się co najmniej 30-procentowym spadkiem ceny ropy, utrzymującym się przez co najmniej pół roku. Miały one miejsce w latach: 1986, 1990/1991, 1997/1998, 2001, 2008 (rys. 1).

Wielu badaczy sądzi, że ostatnie tąpnięcie na rynku ropy naftowej jest analogiczne do sytuacji z 1986 roku, gdy po gwałtownym wzroście cen ropy naftowej w latach 70. świat zwrócił się w stronę mniejszej intensywności zużycia ropy i alternatywnych źródeł energii. Cena ropy między styczniem a lipcem 1986 roku spadła aż o 61\%, z 24,68 do 9,62 dol. za baryłkę [Pach-Gurgul 2016, s. 191]. Z drugiej strony, warto jednak zwrócić uwagę na różnice między tymi wydarzeniami. Przede wszystkim w 1985 roku udział OPEC w rynku wynosił mniej niż 30\%, co oznaczało spadek o prawie 20 punktów procentowych w stosunku do poprzedniego dziesięciolecia - z 49\% w 1976 roku. Najbardziej poszkodowanym krajem była Arabia Saudyjska, której udział spadł z $15 \%$ do nieco ponad $6 \%$. Ceny ropy oscylowały wówczas wokół 25 dol. za baryłkę (ok. 75 dol. w cenach z 2017 roku). Produkcja Arabii Saudyjskiej osiągnęła wtedy 3,6 mln baryłek dziennie, co oznaczało ogromny spadek - z 10 mln baryłek na dobę zaledwie cztery lata wcześniej. Dla Saudyjczyków było to znaczne zmniejszenie dochodów, a co ważniejsze - utrata prestiżu 


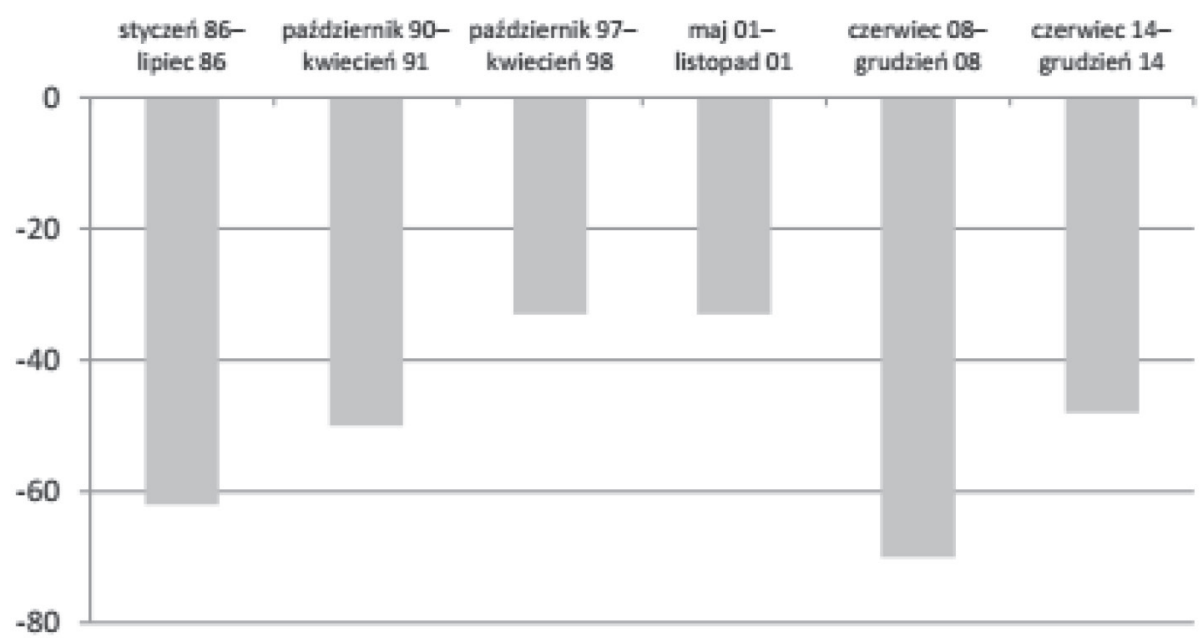

Rys. 1. Spadki cen ropy w latach 1986-2014 [\%]

Źródło: [Pach-Gurgul 2016, s. 192].

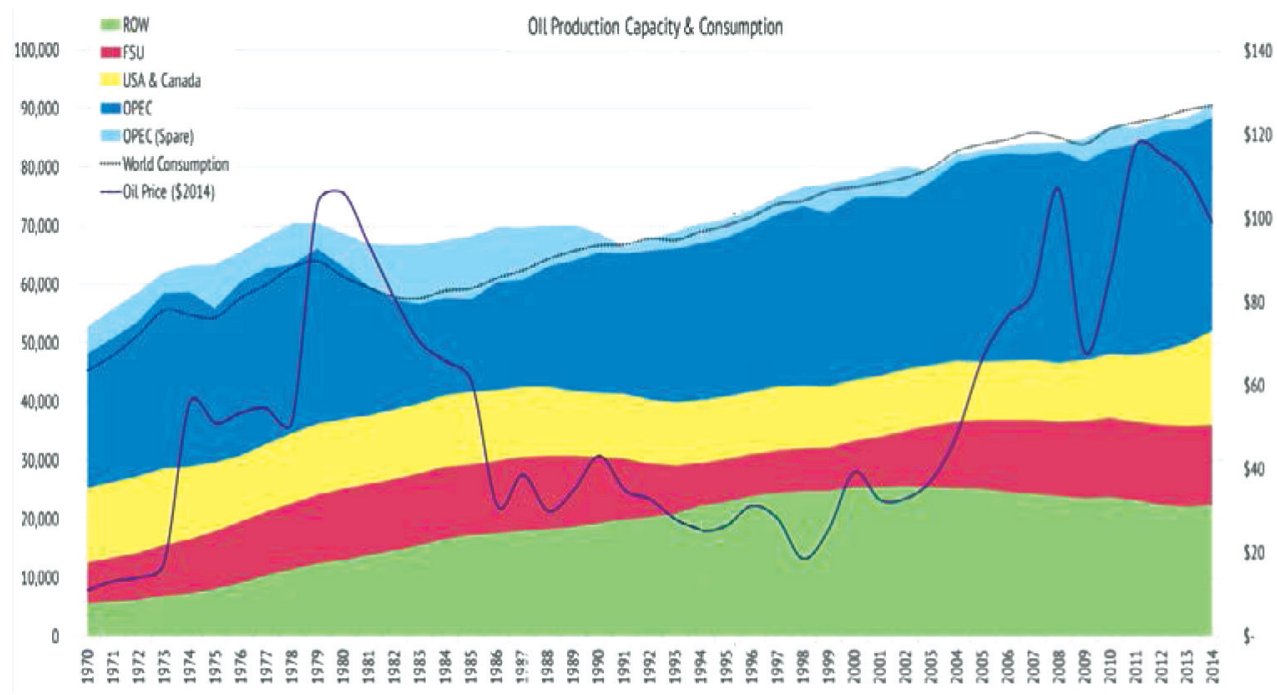

Rys. 2. Produkcja i konsumpcja ropy w latach 1970-2014 (od dołu: reszta świata, dawne ZSRR, USA i Kanada, OPEC, zapas OPEC; linią ciągłą oznaczono poziom światowej konsumpcji, a linią kropkowaną - cenę ropy w wartościach z 2014 roku)

Źródło: [Brown 2015a].

i kontroli nad rynkiem. Z kolei pod koniec 2014 roku udział OPEC w światowym rynku wynosił nadal ponad $40 \%$, co oznaczało spadek o mniej niż $2 \%$ w porówna- 
niu z wcześniejszą dekadą. W tym czasie ceny ropy wyniosły średnio ponad 90 dol. za baryłkę. Warto odnotować, że podczas gdy w latach 80. nawet umiarkowanie wysokie ceny ropy potrafiły znacznie obniżyć popyt i zredukować udział OPEC w rynku, obecnie, przy wyższych cenach, oba te czynniki cechują się dość wysokim poziomem. Niewątpliwie należy także odnotować zmieniający się stosunek popytu do podaży w ciągu ostatnich dekad, co przedstawia rys. 2. Aż do początku XXI wieku możliwości produkcyjne na świecie były wyższe niż zapotrzebowanie na ropę. Od 2004 roku widać jednak zmianę tej tendencji, co stanowi kolejną różnicę między sytuacją z 1986 roku a 2014 [Brown 2015a] .

Warto także pochylić się nad przyczynami tak gwałtownego spadku cen. Według wielu badaczy tendencja ta może okazać się trwała ze względu na dynamiczny postęp technologiczny. Czynnik ten wpływa w znaczny sposób zarówno na podaż - poprzez innowacyjne metody pozyskiwania energii ze źródeł niekonwencjonalnych czy udoskonalanie technik wydobycia ropy - jak i na popyt, gdyż obecnie promuje się bardziej energooszczędne rozwiązania dla przemysłu czy transportu, a także przepisy i procedury, które mają ograniczać negatywne oddziaływanie na klimat i środowisko. Według prognoz, w 2025 roku już ponad 30\% nowych pojazdów będzie wyposażonych w silniki wykorzystujące alternatywne źródła napędu, natomiast w 2022 roku ich cena zrówna się z cenami samochodów spalinowych. Optymistyczne scenariusze przewidują, że w 2040 roku można spodziewać się nawet $715 \mathrm{mln}$ samochodów elektrycznych, które zastąpiłyby $6 \mathrm{mln}$ baryłek dziennego zapotrzebowania na ropę. Politykę taką aktywnie wspierają rządy, które poprzez różnego rodzaju ustawy i programy przyczyniają się do popularyzacji alternatywnych źródeł energii. Oprócz tego rośnie także świadomość społeczna odnośnie do negatywnych skutków nadmiernego wykorzystania tradycyjnych paliw. Według Międzynarodowej Agencji Energii w latach 2015-2021 popyt na ropę zwiększy się o 7,2 mln baryłek dziennie - z 94,4 mln do 101,6 mln, barierę $100 \mathrm{mln}$ dziennie przekraczając zapewne w 2019 roku. Wzrost ten jest niższy, niż oczekiwano, i wynosi średnio $1,2 \%$ rocznie, podczas gdy w latach $2009-2015$ było to $1,7 \%$. Co więcej, po raz pierwszy od 1986 roku zmniejszyły się także inwestycje w sektorze wydobywczym [Hryniewiecki, Jarosz 2016, s. 102]. W 2015 roku nakłady na produkcję ropy zmalały o 24\%. Kolejny spadek zaobserwowano w 2016 roku, przy czym Międzynarodowa Agencja Energii szacuje, że jeśli tendencja ta przedłuży się na trzeci rok z rzędu, coraz bardziej prawdopodobne staje się, że popyt i podaż nie pokryją się na początku lat 20. XXI wieku, co może wywołać nowy cykl zawirowań na rynku ropy. Podczas gdy inwestycje w wydobycie ropy znacznie spadły, coraz większe środki finansowe - na poziomie około $1,8 \mathrm{bln}$ dol. rocznie - są przyciągane przez sektor tzw. zielonych energii. Również wartość subsydiów na konsumpcję paliw kopalnych zmalała w 2015 roku do poziomu 325 mld dol. - z prawie 500 mld zaledwie rok wcześniej, co jednocześnie odzwierciedlało niższe ceny paliw kopalnych, a także przeprowadzone w licznych krajach reformy programów subsydiowania paliw [International Energy Agency 2017]. 
Na spadek cen wpływ miała też strona podażowa. Zapoczątkowana w Stanach Zjednoczonych tzw. rewolucja łupkowa pozwoliła USA na powrót stać się jednym z największych producentów ropy na świecie. W czerwcu 2015 roku produkcja ropy naftowej w Stanach Zjednoczonych wynosiła 9,6 mln baryłek dziennie, co oznacza, że udział tego kraju w światowej produkcji wzrósł z 8\% w 2005 roku do 13\% w 2015 [Gwiazda 2015]. Dzięki rozwojowi technologii szczelinowania hydraulicznego wydobycie ropy w USA wzrosło od 2008 roku o 66\%. Jednocześnie średni koszt produkcji (wliczając koszty inwestycyjne) spadł z około 100 dol. w 2009 roku do 60 dol. w roku 2016 [Interia Biznes 2016]. Mimo iż Amerykanie do chwili powstania tego artykułu nie zdecydowali się na eksport swoich zasobów, zwiększenie krajowej produkcji pozwoliło na znaczne zmniejszenie i uniezależnienie się od paliw z importu, szczególnie z regionów niestabilnych politycznie. Co więcej, wydobycie ropy w kraju pozwala zwiększyć poziom inwestycji, liczbę miejsc pracy czy wpływy podatkowe do budżetu, poprawia bilans handlowy oraz daje możliwość lepszej kontroli wysokości cen [Janus, Zimny 2015]. Amerykańska strategia wydobycia poskutkowała zaistnieniem nadwyżki surowca na rynku, co miało bezpośredni wpływ na gwałtowny spadek cen. Inną konsekwencją tej rewolucji jest również malejący wpływ OPEC na kształtowanie cen [Pach-Gurgul 2016, s. 197-198].

Działania USA sprawiły, że zagrożony został udział w rynku państw bliskowschodnich, szczególnie Arabii Saudyjskiej. Kraje te, chcąc chronić swoją dominującą pozycję, nie miały wyjścia i musiały przystać na niskie ceny ropy, licząc na to, że utrzymujące się długo spadki sprawią, iż wydobycie ropy w Stanach Zjednoczonych przestanie być opłacalne i Amerykanie wycofają się z rynku. Do tej pory strategia Arabii Saudyjskiej polegała na byciu tzw. dostawcą swingującym (swing producer), a więc takim, który może swobodnie manipulować poziomem wydobycia i tym sposobem wpływać na cenę ropy. Od 2014 roku kraj ten zrezygnował jednak z obranej taktyki i postanowił nie zmniejszać produkcji, co razem z ropą łupkową wywołało na rynku nadpodaż i spadek cen. Arabia Saudyjska wolała walczyć o udział w rynku, nawet kosztem niższych wpływów do budżetu, mając nadzieję, że stan ten nie potrwa długo. Taką drogę wybrał cały kartel, czego dowodem jest fakt, że w październiku 2014 roku OPEC produkowała 30,974 mln baryłek ropy dziennie, przekraczając wynoszący $30 \mathrm{mln}$ oficjalny limit. Przy cenie oscylującej wokół 40 dol. za baryłkę eksperci oczekiwali rychłej decyzji o ograniczeniu wydobycia, jednak zrzeszone kraje pozostały nieugięte. Decyzja ta była jasnym sygnałem świadczącym o tym, że organizacja przeorientowała swoje cele i zamiast utrzymywania najbardziej korzystnych cen ważniejsze dla niej stało się utrzymanie stałego udziału poprzez wypchnięcie z rynku ropy łupkowej [Pach-Gurgul 2016, s. 194-195]. Punktem kulminacyjnym strategii OPEC było zrezygnowanie z narzucania limitów wydobycia dla krajów członkowskich na spotkaniu w grudniu 2015 roku. Mimo iż powszechnie wiadomo, że ograniczenia te nie były przestrzegane, warto zwrócić uwagę na korelację pomiędzy faktycznym a ustalonym poziomem produkcji (rys. 3). Wraz z obniżaniem przez OPEC limitu spadało też rzeczywiste 
wydobycie ropy. Co ciekawe, od 1998 roku nigdy nie przekroczyło ono granicy 5 mln baryłek dziennie ponad ustalony limit. Bez górnej granicy kraje miały możliwość dowolnego zwiększenia produkcji, nie narażając się na oskarżenia o nieprzestrzeganie grupowych ustaleń. Krok ten przyspieszył dodatkowo spadek cen ropy na światowych rynkach [Brown 2015b].

\section{Above Target}

OPEC's crude production has exceeded its target for 18 months straight. Now the group has set aside any limits on output and endorsed the current level.

Output Ceiling Crude Production

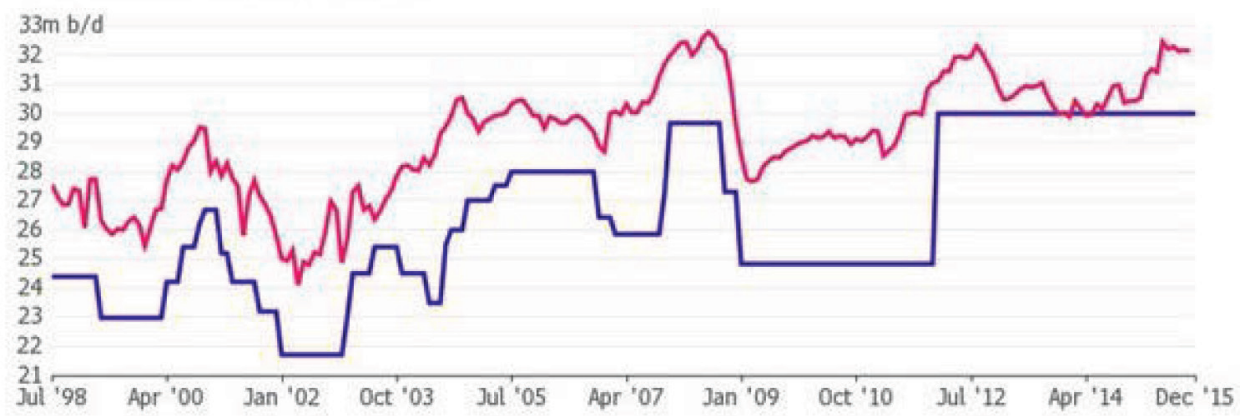

Rys. 3. Porównanie limitów wydobycia OPEC (linia niżej) i realnego wydobycia ropy w krajach członkowskich organizacji (linia wyżej)

Źródło: [Hurst i in. 2015].

Już rok później organizacja zdecydowała się jednak na nowo wprowadzić limity wydobycia i tym samym zmniejszyć podaż surowca. Tym samym po raz pierwszy od ośmiu lat zdecydowano się na cięcia. OPEC zmniejszył produkcję o 1,2 $\mathrm{mln}$ baryłek dziennie - do 32,5 mln. Następnego dnia cena ropy z koszyka OPEC wzrosła o ok. $10 \%$ - z 44,80 dol. 30 listopada 2016 roku do 49,28 dol. 1 grudnia. Ponadto na cięcia zgodziło się także 11 państw niezrzeszonych, m.in. Rosja, co miało zabrać z rynku dodatkowe 600 tys. baryłek dziennie. Ruch ten minimalnie podniósł ceny, jednak od decyzji z końca 2016 roku utrzymują się one na poziomie ok. 45-55 dol. za baryłkę (rys. 4), a więc ok. 2 razy niższym niż w szczytowym momencie w 2012 roku. Po dwóch latach rekordowo niskich cen państwa OPEC uznały, że nie mogą dłużej godzić się na zbyt niskie ceny surowca, a co za tym idzie - niewystarczające dochody budżetowe. Pomimo zwiększonego wydobycia, zyski z eksportu ropy znacznie zmalały, a w latach 2015 i 2016 były ponaddwukrotnie niższe niż w 2012 roku (rys. 5). Dla gospodarek, które funkcjonują, opierając się właśnie na przychodach z ropy, stan ten wiąże się z dużymi problemami, tj. niemożnością sfinansowania działalności państwa i koniecznością wykorzystywania zebranych wcześniej nadwyżek w celu „łatania dziur” [Razzouk i in. 2016]. 


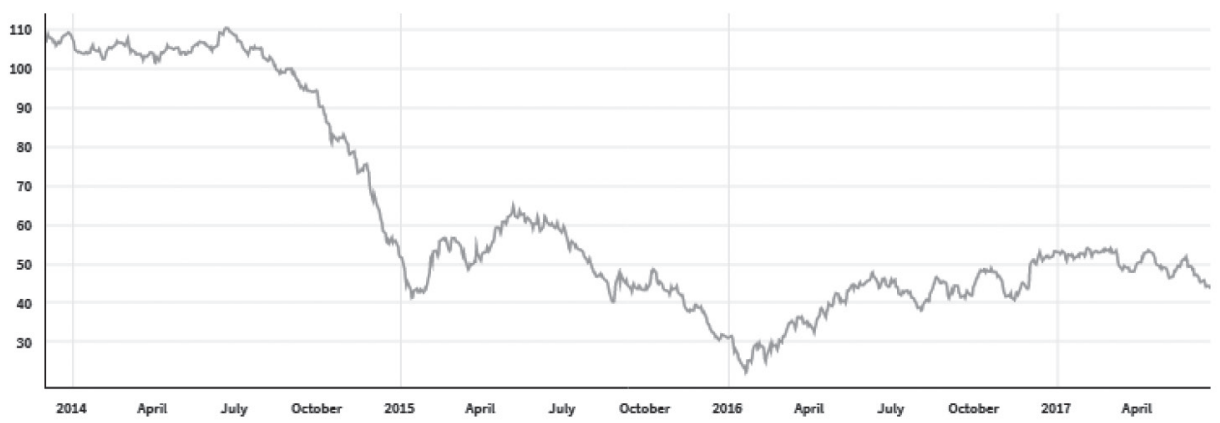

Rys. 4. Ceny ropy z koszyka OPEC w latach 2014-2017

Źródło: opracowanie własne na podstawie [Quandl].

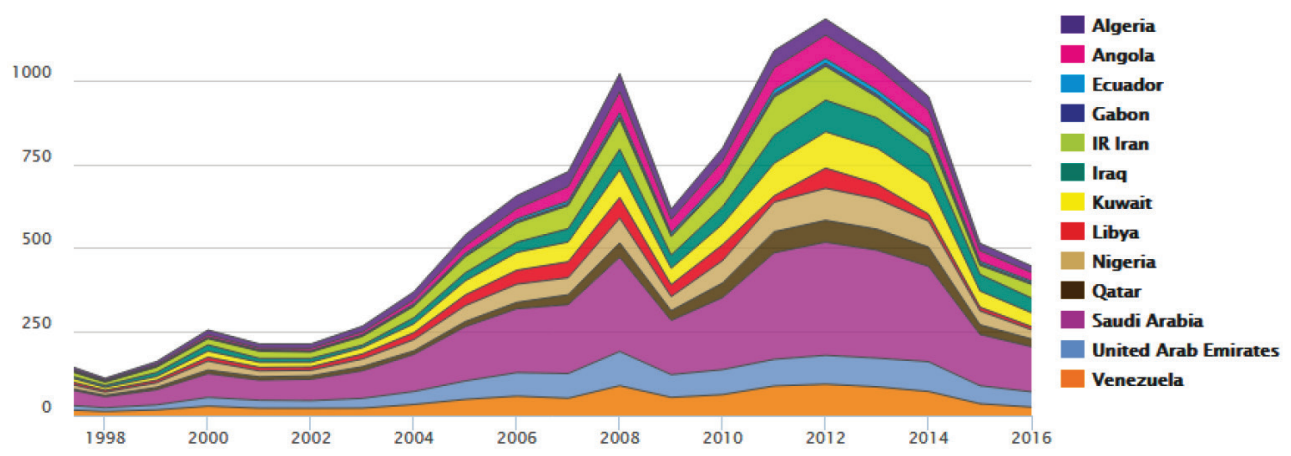

Rys. 5. Dochody z eksportu ropy w poszczególnych państwach OPEC w latach 1998-2016

Źródło: opracowanie własne na podstawie [OPEC 2017, s. 19].

Do nadpodaży przyczyniają się także wydarzenia geopolityczne na Bliskim Wschodzie. Incydentem, który w ostatnim czasie wpłynął znacznie na ilość surowca na rynku, było zniesienie sankcji gospodarczych wobec Iranu i dopuszczenie do eksportu tamtejszej ropy do wielu państw zachodnich. Od zniesienia embarga w styczniu 2016 roku produkcja surowca w tym kraju zwiększyła się o 1/3, osiągając poziom $3,7 \mathrm{mln}$ baryłek dziennie. Plany Iranu zakładają jednak dalsze wzrosty wydobycia - do 4,8 mln w 2021 roku. Ze względu na to, że kraj ten chce nadrobić straty - zarówno finansowe, jak i te dotyczące pozycji w OPEC - powstałe w wyniku wieloletnich sankcji, irańskim władzom udało się wynegocjować limit wydobycia nieco wyższy niż dotychczasowy poziom produkcji. Warto zwrócić także uwagę, że powrót Iranu jako producenta ropy stwarza kolejne pole rywalizacji tego państwa z Arabią Saudyjską, obok sfery politycznej czy militarnej [Krauss, Reed 2016].

Mimo kroków podjętych przez OPEC ceny surowca utrzymują się na stosunkowo niskim poziomie i według prognoz Banku Światowego w 2017 roku nadal będą 
oscylować wokół 55 dol. za baryłkę [Slav 2017]. Chociaż stan ten jest korzystny dla konsumentów ropy i produktów naftowych, państwa utrzymujące się głównie z eksportu ropy, tzw. petrostates, widzą w obecnej sytuacji zagrożenie dla stabilności finansowej, a także politycznej swoich krajów. Przykładem takiej gospodarki jest m.in. Arabia Saudyjska.

\section{Gospodarka Arabii Saudyjskiej jako przykład gospodarki opartej na eksporcie ropy naftowej}

Arabia Saudyjska zajmuje dominującą pozycję w OPEC, będąc nieformalnym przewodniczącym kartelu, a zarazem największym producentem ropy na świecie. Kraj ten, położony na Półwyspie Arabskim, zajmuje 2,15 mln $\mathrm{km}^{2}$, co czyni go 13 największym państwem świata. Graniczy z Jordanią, Irakiem, Kuwejtem, Katarem, Bahrajnem, Zjednoczonymi Emiratami Arabskimi, Omanem oraz Jemenem, a oprócz tego jako jedyny ma dostęp zarówno do Morza Czerwonego, jak i do Zatoki Perskiej. Arabia Saudyjska zamieszkiwana jest przez ponad $28 \mathrm{mln}$ ludzi, z czego 90\% stanowią Arabowie. Społeczeństwo jest tam bardzo homogeniczne, pod względem zarówno etnicznym, jak i religijnym oraz kulturowym - według oficjalnych danych wszyscy obywatele są wyznawcami islamu, a obowiązujące prawo to oparte na Koranie prawo szariatu. Arabia Saudyjska jest państwem o ustroju monarchicznym, a władzę sprawuje król (i jednocześnie szef rządu) Salman bin Abd al-Aziz Al Saud, który objął to stanowisko 23 stycznia 2015 roku, po śmierci brata [The World Factbook].

Gospodarka królestwa jest w dużym stopniu oparta na ropie naftowej - przychody z jej sprzedaży stanowią 42\% PKB, aż 90\% wartości całego eksportu i aż 87\% wszystkich dochodów państwowych. Lwia część tych pieniędzy jest generowana przez państwową spółkę Aramco - giganta branży paliwowej. Co więcej, kraj ma największe rezerwy ropy, szacowane na $18 \%$ światowych zasobów. Jest to też jedyny kraj, który ma możliwość w krótkim czasie znacznie zwiększyć produkcję, a $\mathrm{z}$ drugiej strony dysponuje odpowiednimi oszczędnościami, żeby w razie ograniczenia wydobycia lub spadku cen być w stanie zrealizować budżet [Almajdoub 2017]. Do tej pory sprzedaż surowców pozwoliła Arabii Saudyjskiej na zbudowanie największej gospodarki na Bliskim Wschodzie i 15. na świecie, z PKB (PPP) wynoszącym 1,731 bln dol. w 2016 roku. Także PKB (PPP) w przeliczeniu na osobę plasuje kraj na wysokim 21. miejscu i wynosi 54100 dol. Co ciekawe, także poziom nierówności społecznych jest stosunkowo niski - współczynnik Giniego wynosił w 2013 roku 45,9. Gospodarka Arabii Saudyjskiej rośnie w umiarkowanym tempie, tzn. o 1,2\% w 2016 roku, choć warto także wspomnieć, że zaledwie rok wcześniej było to 3,5\%. W 2015 roku kraj ten znalazł się na 25. miejscu największych eksporterów na świecie, a wartość sprzedaży osiągnęła 182 mld dol. Surowa ropa naftowa stanowiła większość, tj. 55,2\%, całego eksportu, natomiast surowce, produkty chemiczne oraz plastikowe łącznie odpowiadały za 90\%. Towary te trafiły głównie do 
Chin (15\%), USA (11\%), Indii (11\%) oraz Korei Południowej (9,7\%) [Observatory of Economic Complexity]. Na PKB składają się: w 2,4\% rolnictwo, w 42,9\% przemysł i w 54,7\% usługi. Z kolei udział zatrudnienia w tych sektorach to odpowiednio: $6,7 \%, 21,4 \%$ oraz $71,9 \%$. Poziom bezrobocia wynosi $11,2 \%$, z zastrzeżeniem, że dane te dotyczą tylko saudyjskich mężczyzn [The World Factbook]. Warto wspomnieć także, że niektórzy ekonomiści szacują, iż jedynie 30-40\% Saudyjczyków w wieku produkcyjnym ma pracę bądź aktywnie jej poszukuje. Większość z nich jest zatrudniona w sektorze publicznym, który jest postrzegany jako bezpieczniejszy i lepiej płatny. Jeśli zaś chodzi o sektor prywatny, dominują tam emigranci, których w Arabii Saudyjskiej jest ok. $10 \mathrm{mln}$. Często wykonują oni prace fizyczne, których rodowici mieszkańcy nie chcą się podjąć, np. w sektorze budowlanym lub jako pokojówki. Od pewnego czasu władze, będąc świadome tego, że przy spadających cenach ropy i rosnącej populacji taki model rynku jest nie do utrzymania, wprowadzają program tzw. saudyzacji pracowników, tj. zastępowania emigrantów obywatelami Arabii [McDowall 2014]. Przykładowo wprowadzony w 2011 roku program Nitaqat określał kwoty w zakresie minimalnej liczby pracowników saudyjskich. Firmy, w zależności od rozmiaru przedsiębiorstwa i udziału Saudyjczyków w ogólnej liczbie pracowników, otrzymują jeden z czterech statusów: czerwony, żółty, zielony lub platynowy, co wiąże się z nałożeniem pewnych ograniczeń (największych - status czerwony) bądź uzyskaniem przywilejów (największych - status platynowy). Oprócz tego w 2012 roku wprowadzono opłatę w wysokości 2400 SAR (ok. 640 dol.) rocznie za każdego zagranicznego pracownika powyżej liczby zatrudnionych Saudyjczyków [The Ministry of Labor].

Dochody z ropy pozwoliły także Arabii Saudyjskiej na zgromadzenie znacznych rezerw walutowych, które dziś wynoszą 553,7 mld dol. Mimo znacznych spadków cen czarnego złota, a co za tym idzie - również stopnienia części rezerw - nadal pozostają one jednymi z największych na świecie (większymi dysponują jedynie
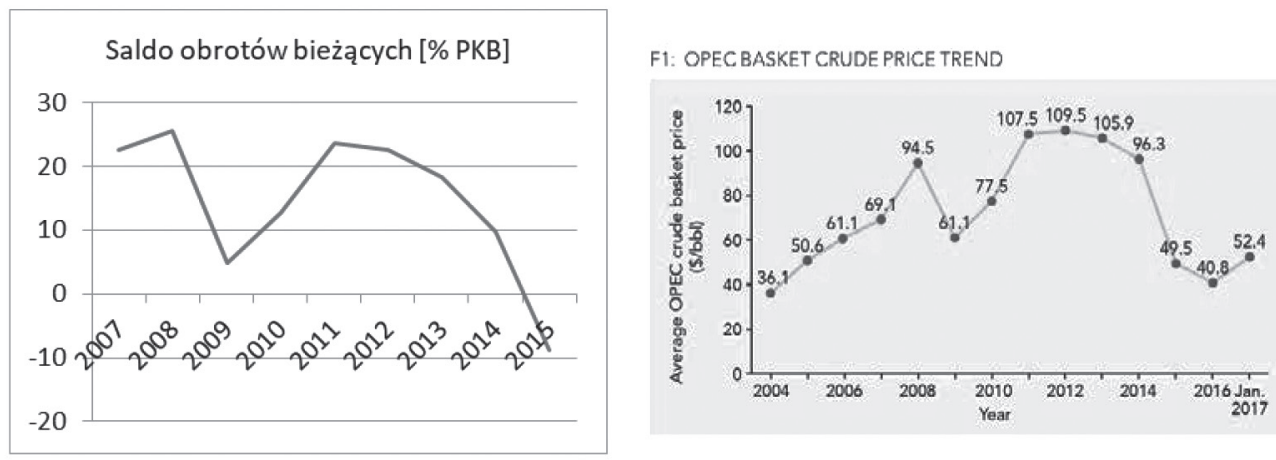

Rys. 6. Saldo obrotów bieżących Arabii Saudyjskiej a ceny ropy z koszyka OPEC

Źródło: opracowanie własne na postawie danych [World Bank 2017; Kar, Pathak 2017]. 
Chiny, Japonia, Unia Europejska oraz Szwajcaria). Także saldo obrotów bieżących przez długi czas utrzymywało się na dodatnim poziomie, co jest ściśle związane z ceną ropy naftowej. Rysunek 6 wyraźnie przedstawia korelację między tymi dwoma wskaźnikami, co oznacza, że w następstwie obniżek cen zmienił się także bilans obrotów bieżących.

Gospodarka saudyjska jest zdominowana przez duże państwowe korporacje, takie jak Aramco, która kontroluje 98\% krajowych rezerw ropy, czy SABIC - siódma największa na świecie firma petrochemiczna [Khorsheed 2015]. Sektor prywatny odpowiada za jedynie 40\% PKB, chociaż prowadzenie działalności nie należy do specjalnie trudnych - według rankingu Doing Business, Arabia Saudyjska zajmuje 94. miejsce (na 190). Najlepiej oceniane są: uzyskiwanie pozwoleń budowlanych (15 miejsce), dostęp do elektryczności (28 miejsce) oraz rejestracja własności (32 miejsce). Z kolei samo zakładanie działalności, choć nieocenione zbyt dobrze (147 miejsce), nie wymaga uiszczania wkładu własnego. Wbrew obiegowym opiniom Saudyjki także mogą posiadać firmę, chociaż procedura jej założenia jest nieco bardziej skomplikowana niż w przypadku mężczyzn [Doing Business]. Władze kraju mocno wspierają rozwój sektora prywatnego, gdyż tylko w ten sposób możliwe jest utrzymanie wysokiego standardu życia, do jakiego przyzwyczaiły mieszkańców Arabii Saudyjskiej dochody z ropy naftowej.

\section{Wpływ zmian na rynku ropy naftowej i sposoby dywersyfikacji gospodarki na przykładzie Arabii Saudyjskiej}

Aby zdać sobie sprawę, w jakim stopniu Arabia Saudyjska zależna jest od rynku ropy naftowej, należy przywołać kilka ważnych wskaźników makroekonomicznych. Po pierwsze, w 2014 roku surowiec ten odpowiadał za 42,6\% nominalnego PKB kraju. Co więcej, aż 76,8\% wszystkich dochodów podatkowych pochodziło właśnie z ropy [IMF 2016]. Wysokie ceny surowca pozwoliły Arabii Saudyjskiej na zgromadzenie pokaźnych rezerw walutowych, wprowadzenie wielu programów socjalnych, rozwój infrastruktury kraju oraz na wiele innych wydatków. W tej sytuacji znacznie zwiększył się próg rentowności ceny ropy, a w sierpniu 2014 roku okazał się wyższy niż ceny surowca (rys. 7). Oznaczało to, że sprzedaż czarnego złota nie wystarcza na pokrycie wydatków budżetowych kraju.

W okresie, gdy ropa notowała rekordowo wysokie ceny, tj. w 2012 roku, wartość eksportu surowca z Arabii Saudyjskiej wyniosła 337,48 mld dol. W 2015 roku spadła jednak o ponad połowę - do 152,91 mld dol., a rok później znowu się obniżyła, do 134,37 mld dol. [OPEC 2017, s. 19]. W kontekście tak dużych spadków konieczne było sięgnięcie po rezerwy walutowe, które kraj zgromadził w czasach dobrobytu. Biorąc pod uwagę skalę niedoborów, jak też wielkość wydatków rządowych, należy stwierdzić, że zasoby te zaczęły maleć w bardzo szybkim tempie. W 2014 roku Arabia Saudyjska dysponowała rezerwami w wysokości 797 mld dol., w ciągu 


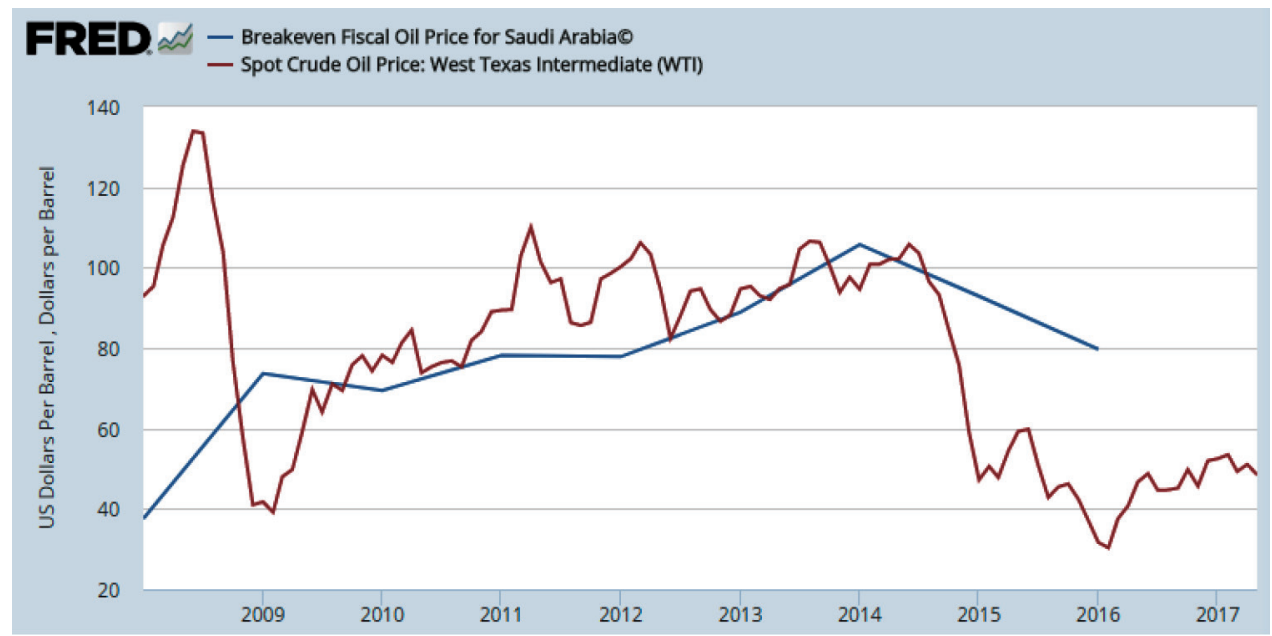

Rys. 7. Próg rentowności (do 2016) a ceny ropy WTI w latach 2008-2017

Źródło: [FRED].

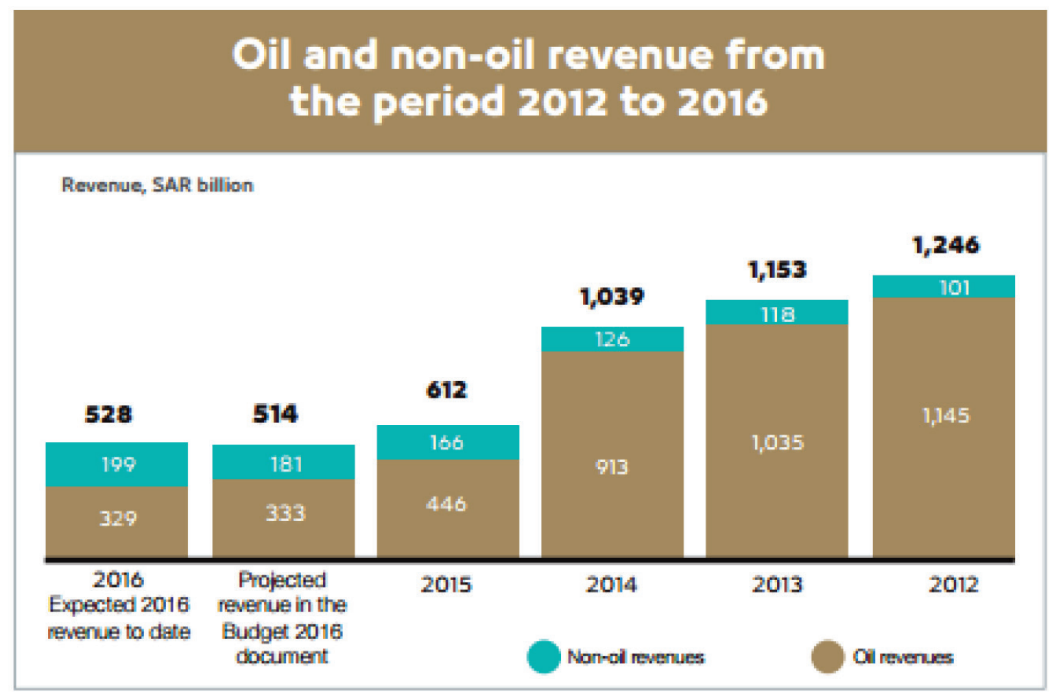

Rys. 8. Dochody podatkowe pochodzące (niżej) i niepochodzące (wyżej) z ropy w latach 2012-2016 Źródło: [Kingdom of Saudi Arabia 2017].

zaś zaledwie 2,5 roku stan ten zmniejszył się o 27\% - do $538 \mathrm{mld}$ dol. [SRSrocco Report 2017]. Według ostrzeżeń MFW, przy obecnym tempie wydatków zapasy wyczerpią się w ciągu zaledwie pięciu lat. Wpływ obniżki cen ropy widać także, kiedy analizuje się dochody podatkowe królestwa (rys. 8). W budżecie na rok 2017 można 
zauważyć dwie ważne rzeczy - po pierwsze, od 2012 roku kwoty te są coraz niższe, natomiast w 2015 roku miał miejsce drastyczny spadek. Z drugiej strony jednak, coraz większym udziałem odznaczają się dochody niepochodzące z ropy. Warto zauważyć także, iż według ówczesnych prognoz dochody te będą o 18 mld SAR (ok. 4,8 mld dol.) wyższe, niż przewidywano w budżecie na 2016 rok.

Na niskich cenach ropy ucierpiały także inne wskaźniki makroekonomiczne, jak deficyt budżetowy oraz dług publiczny. W 2016 roku wydatki rządowe wyniosły 825 mld SAR (ok. 220 mld dol.) i pomimo ich znacznego zmniejszenia - w 2014 roku było to 1,1 bln SAR (ok. 293 mld dol.) - dochody na poziomie 528 mld SAR (ok. 140,8 mld dol.) nie wystarczyły na sfinansowanie całego budżetu. Konieczne było więc zwiększenie długu publicznego do wysokości 316,5 mld SAR (84,4 mld dol.), z czego $2 / 3$ stanowi dług wewnętrzny. Całe zadłużenie stanowi około $12 \%$ PKB w 2016 roku i jest ponadsiedmiokrotnie większe niż w 2014 roku, kiedy rekordowo niski dług wynosił zaledwie 44 mld SAR (ok. 11,7 mld dol.) [Kingdom of Saudi Arabia 2017, s. 12-17].

W takiej sytuacji królestwo mogłaby uratować tylko nagła znaczna podwyżka cen ropy bądź dywersyfikacja gospodarki i stopniowe odejście od czarnego złota jako głównego motoru wzrostu. Po pierwsze więc, Arabia Saudyjska, wraz z innymi państwami OPEC, zmniejszyła wydobycie surowca, co miało wpłynąć na jego cenę. Ważniejszym jednak krokiem było wprowadzenie strategii Vision 2030, na którą składają się bardziej szczegółowe programy. Kluczowym celem planu jest zmniejszenie wydatków publicznych i zwiększenie przychodów niepochodzących z przemysłu naftowego tak, aby zapewnić stabilność finansową, zdywersyfikować źródła dochodów, zwiększyć efektywność wydatków, skoncentrować się na projektach o wysokiej stopie zwrotu, a także zastosować skuteczne systemy monitorowania i oceny wyników [Kingdom of Saudi Arabia 2017, s. 28]. Autorem programu jest następca tronu książę Muhammad, natomiast sam dokument został uznany za neoliberalny szkic prywatyzacji gospodarki, a także największy pakiet reform w całej historii kraju. Warto zauważyć, iż niższe ceny ropy przyspieszyły jedynie to, co nieuniknione. Mimo że Arabia Saudyjska posiada największe rezerwy surowca, które wystarczą na wiele lat, nie można zapomnieć, iż jest to nieodnawialne źródło energii, a co za tym idzie - prędzej czy później się wyczerpie. W związku z tym konieczność uniezależnienia krajowej gospodarki od ropy pojawiłaby się w przyszłości niejako niezależnie od fluktuacji cen surowca.

Vision 2030 jest długoterminową strategią, która określa ramy dla nadchodzących reform, stąd też dość duży poziom ogólności programu. Hasłem przewodnim określającym silne strony kraju jest ,serce arabskiego i islamskiego świata, kuźnia inwestycji i centrum łączące trzy kontynenty" (the heart of the Arab and Islamic worlds, the investment powerhouse, and the hub connecting three continents). Program ten opiera się na trzech filarach: tętniącym życiem społeczeństwie, rozwijającej się gospodarce i ambitnym narodzie (vibrant society, thriving economy, ambitious nation). Zakłada on nie tylko reformy ekonomiczne, ale także socjalne i polityczne, 
których celem jest uczynienie z Arabii Saudyjskiej nowoczesnego państwa na miarę XXI wieku. Pierwszy filar dotyczy bowiem ludności arabskiej, która ma stanowić podstawę dla osiągania kolejnych punktów programu. Mocno wyeksponowana jest tu zgodność z wartościami islamskimi, ale także potrzeba wypracowania odpowiedniej polityki społecznej i zdrowotnej. $\mathrm{Z}$ kolei drugi trzon opiera się na reformach ekonomicznych, które mają stworzyć możliwości rozwoju dla wszystkich obywateli, co obejmuje edukację, tworzenie miejsc pracy, prywatyzację oraz wykreowanie korzystnego otoczenia biznesowego dla wszystkich podmiotów. Ostatnim fundamentem jest skuteczne, przejrzyste, odpowiedzialne, sprawne i wydajne zarządzanie państwem [Kingdom of Saudi Arabia 2016a, s. 13].

Każdy z filarów Vision 2030 podzielony jest na dwa cele ogólne. Następnie dzielą się one na 27 celów branżowych (drugiego stopnia), a dalej - na 96 celów strategicznych (trzeciego stopnia). Podział inicjatyw z zakresu filaru gospodarczego przedstawia poniższa lista (pierwszy poziom to cele ogólne, drugi - branżowe, natomiast trzeci - strategiczne) [Kingdom of Saudi Arabia 2016b, s. 20-30]':

3. Wzrost i dywersyfikacja gospodarki

3.1. Zwiększyć znaczenie sektora prywatnego dla gospodarki

3.1.1. Ułatwić prowadzenie działalności gospodarczej

3.1.2. Odblokować aktywa państwowe dla biznesu

3.1.3. Sprywatyzować wybrane usługi rządowe

3.1.4. Zapewnić utworzenie zaawansowanego rynku kapitałowego

3.1.5. Umożliwić instytucjom finansowym wspieranie wzrostu sektora prywatnego

3.1.6. Przyciągać bezpośrednie inwestycje zagraniczne

3.1.7. Stworzyć specjalne strefy ekonomiczne

3.2. Maksymalizować dochód pozyskany z sektora energetycznego

3.2.1. Zwiększyć lokalny sektor naftowy i gazowy

3.2.2. Zwiększyć produkcję gazu i możliwości dystrybucji

3.2.3. Rozwinąć gałęzie przemysłu związane z sektorem naftowym i gazowym

3.2.4. Zwiększyć udział odnawialnych źródeł w koszyku energetycznym

3.2.5. Zwiększyć konkurencyjność rynku energii

3.3. Odblokować potencjał sektorów niezwiązanych z ropą

3.3.1. Maksymalizować dochód z sektora wydobywczego

3.3.2. Rozwinąć gospodarkę cyfrową

3.3.3. Określić obiecujące gałęzie przemysłu wytwórczego

3.3.4. Zlokalizować przemysł zbrojeniowy

3.3.5. Umożliwić rozwój sektora handlowego

3.3.6. Umożliwić rozwój sektora turystycznego

${ }^{1}$ Przyjęto numerację zgodną z programem Vision 2030, w której za filar gospodarczy odpowiadają właśnie cele nr 3 i 4 . 
3.3.7. Zwiększyć sektor niezwiązany z ropą naftową

3.4. Zwiększyć aktywa i rolę Funduszu Inwestycji Publicznych

3.4.1. Zwiększyć aktywa Funduszu Inwestycji Publicznych

3.4.2. Odblokować nowe sektory za pomocą Funduszu Inwestycji Publicznych

3.4.3. Zlokalizować sektor nowoczesnych technologii i wiedzy za pomocą Funduszu Inwestycji Publicznych

3.4.4. Zbudować strategiczne partnerstwo ekonomiczne za pośrednictwem Funduszu Inwestycji Publicznych

3.5. Promować kraj jako globalne centrum logistyczne

3.5.1. Stworzyć centra logistyczne i poprawić ich funkcjonowanie

3.5.2. Poprawić lokalną, regionalną i międzynarodową łączność sieci handlowych i transportowych

3.6. Dalej integrować krajową gospodarkę regionalnie i globalnie

3.6.1. Wzmocnić plan integracji Rady Współpracy Zatoki Perskiej

3.6.2. Rozwijać powiązania gospodarcze z regionem poza Radą Współpracy Zatoki Perskiej

3.6.3. Rozwijać powiązania gospodarcze z globalnymi partnerami

3.7. Zwiększyć wartość eksportu niepochodzącego z ropy

3.7.1. Wspierać krajowe firmy w umacnianiu ich przywództwa na świecie

3.7.2. Przekształcić obiecujące firmy lokalne w regionalnych i światowych liderów

4. Zwiększenie zatrudnienia

4.1. Rozwijać kapitał ludzki zgodnie z potrzebami rynku pracy

4.1.1. Zbudować ścieżkę uczenia się przez całe życie

4.1.2. Poprawić podstawowe efekty uczenia się

4.1.3. Poprawić dostępność edukacji (zwłaszcza na obszarach wiejskich)

4.1.4. Poprawić pozycje rankingowe instytucji edukacyjnych (np. uniwersytetów)

4.1.5. Rozwijać najzdolniejsze umysły w dziedzinach priorytetowych

4.1.6. Zapewnić dostosowanie wyników edukacyjnych do potrzeb rynku pracy

4.1.7. Rozwinąć szkolenie zawodowe w celu zaspokojenia potrzeb rynku pracy

4.2. Zapewnić równy dostęp do miejsc pracy

4.2.1. Poprawić gotowość młodzieży do wejścia na rynek pracy

4.2.2. Zwiększyć udział kobiet w rynku pracy

4.2.3. Ułatwić integrację osób niepełnosprawnych na rynku pracy

4.3. Umożliwić tworzenie miejsc pracy przez MŚP i mikroprzedsiębiorstwa 4.3.1. Wspierać kulturę innowacji i przedsiębiorczości

4.3.2. Zwiększyć wkład MŚP w gospodarkę 


\subsubsection{Zwiększyć wkład rodzin w gospodarkę}

4.4. Przyciągnąć odpowiednie dla gospodarki zagraniczne talenty

4.4.1. Poprawić warunki mieszkaniowe dla imigrantów

4.4.2. Poprawić warunki pracy dla imigrantów

4.4.3. Pozyskiwać odpowiednie talenty zagraniczne

Strategia ta wydaje się dość szczegółowa, jest to jednak plan na 14 lat, który obejmuje reformy gospodarki jako całości, stąd też konieczne jest jego doprecyzowanie. W ramach Vision 2030 mają funkcjonować pięcioletnie plany, w których określono dokładniejsze cele i metody działania. Na początku wyszczególniono 13 programów, które jednak z biegiem czasu mogą być uzupełniane o inne dokumenty o podobnym charakterze. Do pierwszych zaliczają się m.in. Program restrukturyzacji rządu, Program mierzenia skuteczności, Program strategicznej transformacji Saudi Aramco, Program partnerstwa strategicznego czy Program prywatyzacji. $\mathrm{Na}$ chwilę obecną realizowane są dwa inne programy, również wchodzące w skład Vision 2030 - Program transformacji narodowej 2020 oraz Program równowagi fiskalnej 2020. Pierwszy z nich ma za zadanie zidentyfikować wyzwania stojące przed organami rządowymi w zakresie gospodarki i rozwoju, a także opracować konkretne inicjatywy w odpowiedzi na te wyzwania. Drugi z kolei sprawdza dotychczasowe wydatki inwestycyjne, ich mechanizm zatwierdzania i wpływ gospodarczy [Vision 2030].

Sam Program transformacji narodowej narzuca na organy publiczne konieczność zrealizowania 346 celów, które do pewnego stopnia przypominają pomysły brytyjskiej premier Margaret Thatcher z lat 80. Program w dużym stopniu opiera się na zwiększeniu sektora prywatnego zarówno poprzez ułatwienia dla biznesu, jak i sprzedaż niektórych przedsiębiorstw państwowych, m.in. poczty. Planowane jest także zwiększenie udziału sektora prywatnego w służbie zdrowia czy transporcie, reformy systemu edukacji i wiele innych zmian, realizowanych przez 24 organy i instytucje rządowe. Kolejna idea widoczna w planie to tzw. buy Saudi, a więc zastępowanie dóbr importowanych krajowymi. Obecnie lokalnie produkuje się nieco ponad 1/3 wszystkich towarów, a zgodnie z planem do 2020 roku wartość ta ma zwiększyć się do 50\% - głównie za pomocą przemysłu farmaceutycznego i wytwórczego, a także odnawialnych źródeł energii. Następnym kluczowym punktem jest zwiększenie liczby turystów. Choć Arabia Saudyjska, znana z restrykcyjnego prawa, nie jest wakacyjnym rajem, przyjmuje rocznie 64,5 mln turystów, głównie udających się do Mekki. Plan zakłada nie tylko zwiększenie ich liczby, ale też wydłużenie średniego czasu pobytu czy stworzenie wielu nowych atrakcji, czego wynikiem byłoby również wykreowanie znacznej liczby miejsc pracy [Kerr 2016]. Ambitne cele stawia przed sobą także Ministerstwo Energii, Przemysłu i Surowców Mineralnych. Przede wszystkim dotyczą one uniezależnienia się od ropy, szczególnie w zakresie wartości eksportu dóbr niezwiązanych z ropą, liczby eksporterów czy miejsc pracy w sektorze prywatnym. Wiele podobnych inicjatyw planują także Ministerstwo Finansów oraz Ministerstwo Gospodarki i Planowania. Chodzi tu głównie o zwięk- 
szenie udziału dochodów niepochodzących z ropy oraz udziału sektora prywatnego w PKB [Kingdom of Saudi Arabia 2016c]. Budżet całego przedsięwzięcia wynosi łącznie 268 mld SAR (ok. 76 mld dol.), z czego aż 217 mld przypada na realizację planu w latach 2018-2020.

Z wielu powodów cały program Vision 2030 jest jednak krytykowany. Zachodnie media często wytykają rodzinie królewskiej Arabii Saudyjskiej luksusowy styl życia czy ekstrawaganckie wydatki nawet wtedy, gdy budżet państwa jest nadszarpnięty. Także reformy sektora publicznego wydają się nieskuteczne, gdyż w celu zwiększenia dochodów budżetowych rząd postanowił dodatkowo opodatkować przedsiębiorstwa. Co ważne, są one w dużym stopniu zależne od władz, także dlatego, że większość utrzymuje się z kontraktów rządowych. Należy wspomnieć także, że w 2016 roku odmówiono zapłaty wielu znaczącym wykonawcom, co sprawiło, że rzesza pracowników zagranicznych pozostała bez środków do życia. Również wspominana w pierwszym rozdziale „saudyzacja” nie przynosi skutków, gdyż zatrudnianie imigrantów jest bardziej opłacalne - nawet jeśli wliczyć w to odprawy dla byłych pracowników i kary. W okresie od września 2016 roku do maja 2017 roku zwolniono 50 tys. Saudyjczyków, w miejsce których zatrudniono 170 tys. pracowników zagranicznych. Na krytykę zasługuje także brak liberalizacji w prawach kobiet - mimo iż w programie zapisano zwiększenie ich udziału w ogólnej liczbie pracowników (zaledwie o 8\%), nie zaplanowano nawet rozwiązania palących problemów społecznych, szczególnie zakazu prowadzenia pojazdów czy systemu opieki, który wymaga od kobiet uzyskania zgody mężczyzny na różnego rodzaju czynności, jak choćby wyjście z domu. W polityce rządu Arabii Saudyjskiej nie widać nawet chęci wprowadzenia reform w tym zakresie, o czym świadczy m.in. dotacja w wysokości 3,5 mld dol. dla firmy transportowej Uber, której klientami są w przeważającej większości (85\%) kobiety. Brak zmian w tym obszarze także powoduje ostrą krytykę Zachodu, szczególnie ze strony organizacji walczących o prawa człowieka [Al-Dosari 2017]. Należy wspomnieć także o planowanej prywatyzacji największej firmy naftowej na świecie - Saudi Aramco. Według władz królestwa jest ona warta 2 bln dol., przy czym ocena jej faktycznej rentowności jest stosunkowo trudna ze względu na brak oficjalnych wyników finansowych. Sprzedaż 5\% przedsiębiorstwa planowana jest na drugą połowę 2018 roku, stąd też Arabia Saudyjska stara się jak najbardziej zwiększyć wartość firmy, szczególnie przez próby podwyższenia cen ropy czy obniżenia opodatkowania Aramco - z 85\% do 50\%. Mimo to, eksperci ostrzegają, że transakcja ta może przynieść królestwu mniejsze niż oczekiwane 100 mld dol. zyski. Pomysł sprzedaży naftowego giganta krytykują także saudyjscy komentatorzy, gdyż firma odpowiada za znaczną część dochodów Arabii, a jej pozbycie się w perspektywie długoterminowej budzi obawy o przyszłe zarobki państwa [The Economist 2017]. 


\section{Zakończenie}

Niewątpliwie spadek cen ropy naftowej w znacznym stopniu wpłynął na światową gospodarkę. W jeszcze większym dotknął jednak krajów eksportujących czarne złoto. Mimo prób podejmowanych przez państwa OPEC, nie udało się zwiększyć cen surowca, a co za tym idzie - przywrócić wpływów do budżetu do poprzedniego poziomu. Biorąc pod uwagę przyczyny omawianych fluktuacji na rynku ropy naftowej, szczególnie te związane z postępem technologicznym (mowa tu o innowacyjnych metodach pozyskiwania energii z niekonwencjonalnych źródeł, a także rosnącej popularności energooszczędnych rozwiązań i odnawialnych źródeł energii), można zaryzykować twierdzenie, iż ceny na omawianym rynku w najbliższym czasie nie wrócą do rekordowych wartości z 2008 roku.

Nowa sytuacja wymusiła na eksporterach zmiany w polityce gospodarczej, co obrazuje przykład Arabii Saudyjskiej. Kraj ten, dotychczas budujący swoje bogactwo na wpływach ze sprzedaży surowca, musiał zmierzyć się z typowym dla gospodarek monogałęziowych problemem, jakim były niekorzystne zmiany koniunkturalne. W efekcie, aby zapobiec gospodarczej zapaści, władze Arabii Saudyjskiej musiały wprowadzić program długoterminowych reform, które mają za zadanie uniezależnić kraj od zysków z ropy. Program Vision 2030 w dużej mierze opiera się na rozwijaniu sektora prywatnego, zakładając liczne ułatwienia dla biznesu. $Z$ drugiej strony jednak, podejmuje się kroki w pewnym stopniu ograniczające rozwój prywatnych przedsiębiorstw poprzez wprowadzanie nowych podatków i podwyższeniu części starych. Także inicjatywy takie jak „saudyzacja” nie przynoszą wymiernych korzyści, gdyż zatrudnianie pracowników zagranicznych nadal jest bardziej opłacalne niż zastępowanie ich rodowitymi mieszkańcami Arabii Saudyjskiej. Kontrowersyjnym krokiem jest także plan sprzedania udziałów w państwowej spółce Aramco - gigancie rynku naftowego. Warto jednak odnotować, iż Arabia Saudyjska jest dopiero u progu swojej drogi do w pełni zdywersyfikowanej gospodarki, dlatego też za wcześnie jeszcze na jednoznaczną ocenę wprowadzonych oraz planowanych reform.

\section{Literatura}

Al-Dosari H., 2017, Saudi Arabia's Post-Oil Future, The Cairo Review of Global Affairs, https://www. thecairoreview.com/tahrir-forum/saudi-arabias-post-oil-future/ (23.06.2017).

Almajdoub S., 2017, Can Saudi Arabia Achieve its Dream of a Post-Oil Economy?, Huffington Post, http://www.huffingtonpost.com/entry/can-saudi-arabia-achieve-its-dream-of-a-post-oil-economy_us_58f0fad8e4b048372700d7c9 (31.05.2017).

Brown S., 2015a, Why Today's Oil Bust Is Not Like The 1980s, http://oilprice.com/Energy/Energy-General/Why-Todays-Oil-Bust-Is-Not-Like-The-1980s.html (16.06.2017).

Brown S., 2015b, OPEC Isn't Dead. It's Shifting Strategies, http://oilprice.com/Energy/Energy-General/OPEC-Isnt-Dead-Its-Shifting-Strategies.html (21.06.2017). 
Doing Business, Ease of Doing Business in Saudi Arabia, http://www.doingbusiness.org/data/exploreeconomies/saudi-arabia (31.05.2017).

FRED, Economic Research at the Federal Reserve Bank of St. Louis, https://fred.stlouisfed.org/series/ SAUPZPIOILBEGUSD (22.06.2017).

Gwiazda A., 2015, Geopolityczne następstwa rewolucji łupkowej w USA, http://geopolityka.org/analizy/adam-gwiazda-geopolityczne-nastepstwa-rewolucji-lupkowej-w-usa (19.06.2017).

Hryniewiecki R., Jarosz R., 2016, Polityczno-ekonomiczne implikacje niskich cen ropy na światowych rynkach dla państw OPEC, Sprawy Międzynarodowe (LXIX).

Hurst L., Lee J., Razzouk N., 2015, OPEC Unity Shattered as Saudi-Led Policy Leads to No Limits, Bloomberg, https://www.bloomberg.com/news/articles/2015-12-04/opec-unity-shattered-as-saudi-led-policy-leads-to-no-limits-ihs9xu51 (21.06.2017).

IMF, 2016, Economic Diversification in Oil-Exporting Arab Countries, https://www.imf.org/external/ np/pp/eng/2016/042916.pdf (22.06.2017).

Interia Biznes, 2015, Ceny ropy dtugo utrzymają się na poziomie 45-55 dolarów, http://biznes.interia. $\mathrm{pl} /$ news/ceny-ropy-dlugo-utrzymaja-sie-na-poziomie-45-55-dolarow,2435162,3142 (19.06.2017).

International Energy Agency, 2017, World Energy Outlook 2016 - Executive Summary.

Janus D., Zimny M., 2015, Wpływ cen gazu i ropy na wydobycie węlowodorów niekonwencjonalnych w USA, Wiadomości, nr 4(204).

Kar S., Pathak Y., 2017, Oil Price Fluctuations, Oil \& Gas Financial Journal, vol. 14, issue 4.

Kerr S., 2016, Five goals of Saudi Arabia's ambitious transformation plans, Financial Times, https:// www.ft.com/content/cbb86ed2-2e38-11e6-a18d-a96ab29e3c95 (22.06.2017).

Khorsheed M.S., 2015, Saudi Arabia: From Oil Kingdom to Knowledge-Based Economy, Middle East Policy, vol XXII, no. 3, Fall.

Kingdom of Saudi Arabia, 2016a, Vision 2030, http://vision2030.gov.sa/sites/default/files/report/Saudi_Vision2030_EN_0.pdf (22.06.2017).

Kingdom of Saudi Arabia, 2016b, KSA Vision 2030. Strategic Objectives and Vision Realization Programs, http://www.vision2030.gov.sa/download/file/fid/1319 (22.06.2017).

Kingdom of Saudi Arabia, 2016c, National Transformation Program 2020, http://vision2030.gov.sa/ sites/default/files/NTP_En.pdf (23.06.2017).

Kingdom of Saudi Arabia, 2017, 2017 Budget, https://www.mof.gov.sa/en/budget2017/Documents/ The_National_Budget.pdf (22.06.2017).

Krauss C., Reed S., 2016, OPEC Reaches Deal to Limit Production, Sending Prices Soaring, The New York Times, https:/www.nytimes.com/2016/11/30/business/international/opec-energy-oil-saudiiran.html?mcubz=2 (21.06.2017).

McDowall A., 2014, Saudi Arabia Doubles Private Sector Jobs in 30-month Period, Al Arabiya English, http://english.alarabiya.net/en/business/2014/01/20/Saudi-Arabiya-doubles-number-of-citizens-in-private-sector-jobs.html (31.05.2017).

Observatory of Economic Complexity, Saudi Arabia, http://atlas.media.mit.edu/en/profile/country/sau/ (31.05.2017).

OPEC, 2017, Annual Statistical Bulletin 2017, http://www.opec.org/opec_web/static_files_project/me$\mathrm{dia} /$ downloads/publications/ASB2017 13062017.pdf (21.06.2017).

Pach-Gurgul A., 2016, Główne determinanty wahań cen ropy naftowej na świecie na przełomie lat 2014/2015, [w:] Prace Komisji Geografii Przemystu Polskiego Towarzystwa Geograficznego, nr 30(3).

Quandl, https://www.quandl.com/data/OPEC/ORB-OPEC-Crude-Oil-Price (21.06.2017).

Razzouk N., Rascouet A., Motevalli G., 2016, OPEC Confounds Skeptics, Agrees to First Oil Cuts in 8 Years, Bloomberg, https://www.bloomberg.com/news/articles/2016-11-30/opec-said-to-agree-oilproduction-cuts-as-saudis-soften-on-iran (21.06.2017).

Slav I., 2017, World Bank Maintains Oil Price Forecast At \$55, http://oilprice.com/Energy/Oil-Prices/ World-Bank-Maintains-Oil-Price-Forecast-At-55.html (21.06.2017). 
SRSrocco Report, 2017, Bankrupting OPEC. One Million Barrels Of Oil At A Time, https://srsroccoreport.com/bankrupting-opec-one-million-barrels-of-oil-at-a-time/ (22.06.2017).

The Economist, 2017, A King-To-Be's Ransom. The Prospects for the World's Biggest IPO, http://www. economist.com/news/business/21723872-saudi-aramco-cannot-be-seen-isolation-kingdom-itfunds-prospects-worlds (23.06.2017).

The Ministry of Labor, The Nitaqat Program, http://www.itu.int/net4/wsis/stocktaking/projects/FileManager/DownloadProjectFile?fileId=f0b530fb-d5f9-4916-832a-f2bfcff381ad (31.05.2017).

The World Factbook, Saudi Arabia, https:/www.cia.gov/library/publications/the-world-factbook/geos/ sa.html (31.05.2017).

Vision 2030, How to Achieve Our Vision, http://vision2030.gov.sa/en/node/125 (22.06.2017).

World Bank, http://data.worldbank.org/ (31.05.2017). 